\title{
Evaluation of infertility in women from an industrial area in Telangana, India by diagnostic hysterolaparoscopy: can it explain the unexplained?
}

\section{Leena Kanungo*, Mylavarapu Haritha, Nerakh Chaitanya, Katroth Sangeetha}

Department of Obstetrics and Gynecology, ESIC Hospital, Hyderabad, Telangana, India

Received: 21 April 2018

Accepted: 27 April 2018

*Correspondence:

Dr. Leena Kanungo,

E-mail: leenarout@yahoo.com

Copyright: () the author(s), publisher and licensee Medip Academy. This is an open-access article distributed under the terms of the Creative Commons Attribution Non-Commercial License, which permits unrestricted non-commercial use, distribution, and reproduction in any medium, provided the original work is properly cited.

\begin{abstract}
Background: Infertility with a prevalence of $10-15 \%$ worldwide has been showing a rising trend. Diagnostic hysterolaparoscopy (DHL) procedure in infertility cases uncovers conditions which even a detailed clinical examination or hysterosalpingography or transvaginal ultrasound can miss. Correction of these factors improves chances of conception, naturally or by subsequent ART procedures.

Methods: This is a prospective study conducted from January 2014 to December 2015. The objective of this study is to evaluate the factors causing infertility by diagnostic hystertolaparoscopy among primary and secondary infertility women coming from an industrial area, attending infertility clinic at Employees State Insurance Corporation Hospital, Telangana. 80 cases of primary infertility (65\%)and secondary infertility (35\%) belonging to age group of 19 to 35 years and above, satisfying the inclusion criteria underwent a systematic way of evaluation by diagnostic hysteroscopy followed by diagnostic laparoscopy procedure.

Results: $40.38 \%$ of primary infertility and $35.72 \%$ of secondary infertility had abnormal pelvic pathology. $27 \%$ of primary and $32.14 \%$ of secondary infertility had abnormal intrauterine abnormality. Diagnostic hysteroscopy found intrauterine septum and endometrial polyp in $12.5 \%$ and tubal ostial fibrosis in $5 \%$ of total cases. Pelvic peritoneal adhesion $(23.75 \%)$, pelvic endometriosis $(13.75 \%)$ and tubal pathology (18.75\%) were most common laparoscopic findings. $32.5 \%$ of all cases had no significant abnormality. Bilateral tubal block was seen in $20 \%$ of cases on chromopertubation. DHL also facilitated operative interventions like adhesionolysis, endometriotic tissue ablation, ovarian cyst drilling, septal resection, polypectomy in the same sitting.

Conclusions: DHL procedure has become the gold standard diagnostic modality, as it explains 30-70\% of factors that remained undetected during routine investigative workup of female infertility, especially those grouped under unexplained infertility. Industrial toxin exposure may lead to infertility as this study among industrial workers showed a greater incidence of tubo-peritoneal pathology than other factors.
\end{abstract}

Keywords: Diagnostic, Hysteroscopy, Infertility, Laparoscopy

\section{INTRODUCTION}

Around one million couples worldwide require fertility treatment. Infertility is defined as the inability to conceive within 12 months or more of unprotected sexual intercourse or exposure to sperm. ${ }^{1}$ Primary infertility is inability to conceive at all, in any way, even after one year of effective sexual exposure without any use of contraception. Secondary infertility refers to inability to conceive following a previous pregnancy irrespective of its outcome. Around 60-80 million couples across the globe are infertile. The fecundability of a normal couple is around $20-25 \% .^{2}$ On this basis, approximately $90 \%$ of couples should conceive by the end of 12 months of 
regular married life. The apparent decline in secondary infertility probably reflects a relative increase in incidence of tubal ligation. It is estimated that the percentage of infertility in women aged 19-26 years is $8 \%$, which increases to $13-14 \%$ in women aged $27-34$ years and $18-28 \%$ between $35-39$ years. ${ }^{3}$ Early detection of factors affecting fertility can give couples a greater chance of achieving a successful pregnancy. The female partner is often subjected to a battery of tests in search of a reason causing her childlessness. But an infertility work up will be incomplete without a diagnostic laparoscopy and hysteroscopy, whenever and wherever feasible. Among the various causes attributing to infertility, diseases like tuberculosis, STD, endometriosis, exposure to harmful environmental factors such as industrial pollutants like chemicals, dye, solvents and a stressful lifestyle play a significant role. The anatomical changes made by some of these factors are infrequently picked up by tests like an ultrasound or hysterosalpingography thereby classifying them under unexplained infertility. Generally, unexplained infertility accounts for $25 \%$ to $30 \%$ of causes of infertility. Multiple studies have found to some extent explanation to this so called unexplained infertility only after a thorough endoscopic evaluation. Upto $70 \%$ of these abnormalities can be detected by diagnostic hysterolaparoscopy (DHL) as a detailed clinical examination or hysterosalpingography or ultrasound sometimes may miss. Hence, DHL has become the single most important diagnostic modality especially for unexplained infertility. The objective of this study is to evaluate factors affecting fertility among primary and secondary infertile women coming from an industrial area by a single step diagnostic hysterolaparoscopy procedure and whether these factors affecting fertility in women residing and working in industrial area any different from general.

\section{METHODS}

This is a prospective study of a two year period from January 2014 to December 2015 involving 80 cases of both primary and secondary infertility women belonging to age group of 19 to 35 years and above, attending infertility clinic of the Gynecological Department of employees' state insurance corporation (ESIC) hospital located in an industrial development area of Hyderabad, Telangana.

\section{Inclusion criteria}

- Women in age group of 19-45 years

- Primary or secondary infertility

- Normal semen analysis of male partner

- No detectable clinical abnormality

- Normal hormonal profile (se. TSH, FSH, LH, Prolactin)

- Inconclusive HSG finding

- No detectable abnormality in pelvic ultrasound

- Previous treatment with 3 or more cycles of ovulation induction
- Unexplained infertility

\section{Exclusion criteria}

- Male factor infertility

- Sexual problem with either of the partner

- Abnormal hormonal profile like hypothyroidism, hyperprolactinemia etc.

- Detectable pelvic pathology clinically, by ultrasound or hysterosalpingography

- Acute pelvic infection

- Anaesthesia contraindicated to hysterolaparoscopy.

80 cases of women with primary and secondary infertility were randomly selected and grouped based on the above selection criteria. Out of them,52 cases $(65 \%)$ were in primary infertility and 28 cases $(35 \%)$ were in secondary infertility group. The duration of infertility was one to seven years. They were admitted in ESIC hospital, Hyderabad, Telangana from a period between January 2014 to December 2015, for evaluation of infertility by diagnostic hysterolaparoscopy.

Hospitalization was done a day prior to this invasive procedure for pre anaesthesia checkup and preparing preoperative steps. An informed consent was obtained from all the cases. DHL was planned during immediate post menstrual period. A partial lithotomy position was preferred for the two combined procedures and all cases were administered general anaesthesia.

Diagnostic Hysteroscopy was first conducted using Bettochi's $4 \mathrm{~mm}$, 30-degree optic, rigid hysteroscope from Karl Storz, Germany. A quick systematic examination of endocervical followed by endometrial cavity including fundus, both ostia, anteroposterior and lateral walls was done. Any abnormal findings like septum, polyp, fibroid, adhesions, osteal fibrosis were recorded. After the procedure, an uterine elevator was kept intracervically and next step of diagnostic laparoscopy was conducted. The pelvic reproductive organs, pelvic side wall and pouch of Douglas were closely observed using a 30-degree Hopkins telescope from Karl Storz, Germany.

Any deviation from normalcy like pelvic, peritubal or periovarian adhesions, endometriosis, ovarian cysts, fibroadenoma, hydrosalpinx or uterine anomaly were noted. A chromopertubation was performed by injecting 10 to $20 \mathrm{cc}$ of $0.5 \%$ methylene blue dye transcervically. Spillage of dye from each or both fimbrial ends of fallopian tubes were observed and recorded. After a thorough diagnostic evaluation, any operative intervention like adhesionolysis, fulguration, ablation of endometriotic areas, drilling of ovarian cyst, septal resection or polypectomy was done, if needed. In one case excision of transverse vaginal septum was done. If postoperative recovery was good, the patient was discharged after 24-48 hours of endoscopy. The results of 
this prospective study was analyzed by descriptive statistics. Microsoft office 2007 was used for making charts and tables for statistical analysis.

\section{RESULTS}

Out of a total of 80 cases, 52 cases $(65 \%)$ were in Primary infertility group and 28 cases $(35 \%)$ were in the secondary infertility group of the study.

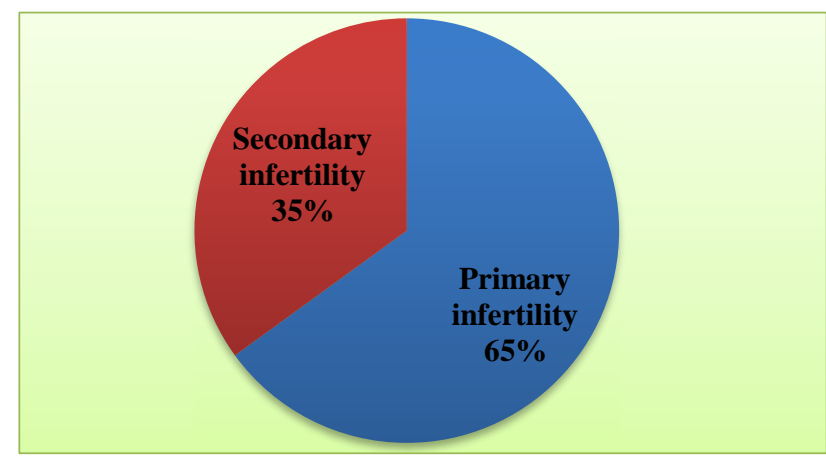

Figure 1: Distribution of primary and secondary infertility cases.

Table I shows the age group wise distribution of cases. Majority (61.54\%) of cases of primary infertility and $57.14 \%$ of secondary infertility cases were in age group distribution of 25-34 years. 22.5\% were in 19-24 years age group and $17.5 \%$ belonged to 35 years and above age group.

Table 1: Distribution of cases by age group.

\begin{tabular}{|lllllll|}
$\begin{array}{l}\text { Age } \\
\text { group } \\
\text { (Years) }\end{array}$ & \multicolumn{2}{l}{$\begin{array}{l}\text { Primary } \\
\text { infertility }\end{array}$} & \multicolumn{2}{l}{$\begin{array}{l}\text { Secondary } \\
\text { infertility }\end{array}$} & \multicolumn{2}{ll}{ Both } \\
\hline $19-24$ & 26.92 & 14 & 14.29 & 04 & 22.5 & 18 \\
\hline $25-34$ & 61.54 & 32 & 57.14 & 16 & 60 & 48 \\
\hline$>35$ & 11.54 & 06 & 28.57 & 08 & 17.5 & 14 \\
\hline Total & 100 & 52 & 100 & 28 & 100 & 80 \\
\hline
\end{tabular}

Table 2 shows abnormal hysteroscopic findings in the primary and secondary infertility group in percentage.

Table 3 shows percentage of hysteroscopic intervention done in the same session.

Five cases $(6.25 \%)$ had septate and subseptate uterus on diagnostic hysteroscopy. One of the septate uterus also had transverse vaginal septum.

Transcervical septal resection was done using monopolar energy in the two cases of subseptate uterus in the same sitting and septal resection of 3 cases of septate uterus was done in a separate elective procedure along with the excision of transverse vaginal septum in the isolated case.
Table 2: Diagnostic hysteroscopy abnormality.

\begin{tabular}{|c|c|c|c|c|c|c|}
\hline \multirow{2}{*}{$\begin{array}{l}\text { Type of } \\
\text { abnormality }\end{array}$} & \multicolumn{2}{|c|}{$\begin{array}{l}\text { Primary } \\
\text { infirtility }\end{array}$} & \multicolumn{2}{|c|}{$\begin{array}{l}\text { Secondary } \\
\text { infirtiity }\end{array}$} & \multicolumn{2}{|c|}{ total } \\
\hline & $\%$ & $\mathbf{n}$ & $\%$ & $\mathbf{n}$ & $\%$ & $\mathbf{n}$ \\
\hline $\begin{array}{l}\text { Intrauterine } \\
\text { septum }\end{array}$ & 5.76 & 03 & 7.14 & 02 & 6.25 & 05 \\
\hline $\begin{array}{l}\text { Endometrium } \\
\text { polyp }\end{array}$ & 5.76 & 03 & 7.14 & 02 & 6.25 & 05 \\
\hline $\begin{array}{l}\text { Submucous } \\
\text { myoma }\end{array}$ & 3.84 & 02 & 3.57 & 01 & 3.75 & 03 \\
\hline $\begin{array}{l}\text { Atrophic } \\
\text { endometrium }\end{array}$ & 0 & 0 & 3.57 & 01 & 1.25 & 01 \\
\hline $\begin{array}{l}\text { Tubal ostial } \\
\text { fibrosis }\end{array}$ & 1.92 & 01 & 10.71 & 03 & 5 & 04 \\
\hline $\begin{array}{l}\text { Hypoplastic } \\
\text { uterus }\end{array}$ & 1.92 & 01 & 0 & 0 & 1.25 & 01 \\
\hline Synechiae & 0 & 0 & 7.14 & 02 & 2.5 & 02 \\
\hline Cervical polyp & 1.92 & 01 & 7.14 & 02 & 3.75 & 03 \\
\hline
\end{tabular}

Table 3: Hysteroscopic interventions done in same sitting.

\begin{tabular}{|lll}
\hline Type of operative hysteroscopy & $\%$ & n \\
\hline Septal resection & 2.5 & 02 \\
\hline Endometrial polypectomy & 6.25 & 05 \\
\hline Synaechiolysis & 2.5 & 02 \\
\hline
\end{tabular}

Five cases $(5.76 \%$ of primary and $7.14 \%$ of secondary infertility) had endometrial polyp, mostly functional in nature. Polypectomy was done in all these 5 cases as they were cornual and fundally located.

Table 4: Diagnostic laparoscopy abnormalities.

\begin{tabular}{|c|c|c|c|c|c|c|}
\hline \multirow{2}{*}{$\begin{array}{l}\text { Type of } \\
\text { abnormality }\end{array}$} & \multicolumn{2}{|c|}{$\begin{array}{l}\text { Primary } \\
\text { infertility }\end{array}$} & \multicolumn{2}{|c|}{$\begin{array}{l}\text { Secondary } \\
\text { infertility }\end{array}$} & \multicolumn{2}{|l|}{ Total } \\
\hline & $\%$ & n & $\%$ & $\mathbf{n}$ & $\%$ & $\mathbf{n}$ \\
\hline $\begin{array}{l}\text { Pelvic } \\
\text { endometriosis }\end{array}$ & 15.38 & 08 & 10.71 & 3 & 13.75 & 11 \\
\hline $\begin{array}{l}\text { Pelvic } \\
\text { adhesiions }\end{array}$ & 23.08 & 12 & 25 & 7 & 23.75 & 19 \\
\hline $\begin{array}{l}\text { Tubal } \\
\text { pathology }\end{array}$ & 17.3 & 09 & 21.43 & 06 & 18.75 & 15 \\
\hline $\begin{array}{l}\text { Ovarian } \\
\text { pathology }\end{array}$ & 7.7 & 04 & 3.57 & 01 & 6.25 & 05 \\
\hline $\begin{array}{l}\text { Polycystic } \\
\text { ovary }\end{array}$ & 11.54 & 06 & 0 & 0 & 7.5 & 06 \\
\hline Adenomyosis & 0 & 0 & 10.71 & 03 & 3.75 & 03 \\
\hline $\begin{array}{l}\text { Uterine } \\
\text { anomaly }\end{array}$ & 5.77 & 03 & 3.57 & 1 & 5 & 04 \\
\hline $\begin{array}{l}\text { Fibroid } \\
\text { uterus }\end{array}$ & 1.92 & 01 & 7.14 & 02 & 3.75 & 03 \\
\hline
\end{tabular}

$3.75 \%$ had distorted cavity due to presence of submucous myoma. Ostial fibrosis ( 2 bilateral and 2 unilateral) was present in 4 cases $(5 \%)$ suggestive of tubal block. 
One case on diagnostic hysteroscopy revealed a small cavity (hypoplastic uterus). Two cases of secondary infertility had intrauterine adhesion s/o Asherman's synechiae. Synaechiolysis was done using monopopolar cutting scissors. Three cases of endocervical polyp were diagnosed on hysteroscopic evaluation.

Table 5: Laparoscopic intervention done in same sitting.

\begin{tabular}{|lll|}
\hline Type of operative intervention & $\%$ & $\mathrm{n}$ \\
\hline Adhesionolysis & 13.75 & 11 \\
\hline Endometriosis ablation, fulguration & 12.5 & 10 \\
\hline Fimbrial cystectomy & 5.0 & 04 \\
\hline Ovarian drilling & 7.5 & 06 \\
\hline Salpingectomy & 2.5 & 02 \\
\hline
\end{tabular}

Table 4 and 5 depicts the statistical findings of diagnostic laparoscopic abnormalities and the type of the laparoscopic interventions done in same session.

The most common pathology observed in diagnostic laparoscopy was pelvic adhesions (23.75\%). These adhesions were flimsy to dense in nature, mostly located in the adnexia in peritubal, periovarian region, lateral pelvis peritoneum and in sigmoid colon area. One case of secondary infertility had dense adhesion involving omentum, bowels with obliteration of pouch of Douglas due to severe endometriosis. Adhesionolysis was done in eleven $(13.75 \%)$ of the cases.

Table 6: Normal and abnormal findings in diagnostic hysterolaparoscopy.

\begin{tabular}{|c|c|c|c|c|c|}
\hline \multirow[t]{2}{*}{ Procedure } & \multirow[t]{2}{*}{ findings } & \multicolumn{2}{|c|}{$\begin{array}{l}\text { Diagnostic } \\
\text { hysteroscopy }\end{array}$} & \multicolumn{2}{|c|}{$\begin{array}{l}\text { Diagnostic } \\
\text { laparoscopy }\end{array}$} \\
\hline & & $\mathbf{N}$ & $\%$ & $\mathbf{N}$ & $\%$ \\
\hline \multirow{2}{*}{$\begin{array}{l}\text { Primary } \\
\text { infertility } \\
\mathrm{N}=52\end{array}$} & $\begin{array}{l}\text { normal } \\
\text { findings }\end{array}$ & 38 & 73 & 31 & 59.62 \\
\hline & $\begin{array}{l}\text { Abnormal } \\
\text { findings }\end{array}$ & 14 & 27 & 21 & 40.38 \\
\hline \multirow{2}{*}{$\begin{array}{l}\text { Secondary } \\
\text { infertility } \\
\mathrm{N}=28\end{array}$} & $\begin{array}{l}\text { Normal } \\
\text { findings }\end{array}$ & 19 & 67.86 & 18 & 64.28 \\
\hline & $\begin{array}{l}\text { Abnormal } \\
\text { findings }\end{array}$ & 09 & 32.14 & 10 & 35.72 \\
\hline Total & & 80 & & 80 & \\
\hline
\end{tabular}

$15.38 \%$ of primary infertility and $10.71 \%$ of secondary infertility cases had mild to severe pelvic endometriosis seen as areas of puckering with bluish black spots and nodules, pelvic congestion, pelvic adhesions, loculated cysts over serosal surface of uterus and endometrioma. Ablation and fulguration in ten of these endometriosis cases were done in same sitting.

Tubal pathology was seen in $17.3 \%$ of primary and $21.43 \%$ of secondary infertility cases. Mild to moderate hydrosalpinx were seen in $6.25 \%$ of these cases. Fimbrial agglutinisation, fimbrial cysts, tubal surface granulomas, tubal congestion, lymphocycts and 2 cases of short, thick tubes were suggestive of tuberculosis. Peritoneal fluid and endometrial sampling were sent for T.B. DNA PCR. Salpingectomy was done in two cases and fimbrial cystectomy done in four cases.

Three cases of secondary infertility had adenomyosis. Six (7.5\%) cases had polycystic ovaries that ultrasound did not report. Laparoscopic ovarian drilling was done in all the six cases. Four cases (5\%) of infertility had Mullerian anomaly out of which three had arcuate with septate uterus, one with hypoplastic uterus. $32.5 \%$ of 80 cases (18 of primary and 8 of secondary infertility cases) had no significant findings on DHL. They are grouped here as unexplained infertility.

Table 6 shows that $27 \%$ of primary infertility and $32.14 \%$ of secondary infertility cases had intrauterine defects and $40.38 \%$ of primary infertility and $35.72 \%$ of secondary infertility cases had pelvic pathology. 14 of total 80 cases $(17.5 \%)$ had both hysteroscopic and laparoscopic abnormalities.

Table 7: Chromopertubation test result.

\begin{tabular}{|lccccccc|}
\hline $\begin{array}{l}\text { Findings of } \\
\text { cpt test }\end{array}$ & $\begin{array}{l}\text { Primary } \\
\text { infertility }\end{array}$ & $\begin{array}{l}\text { Secondary } \\
\text { infertility }\end{array}$ & Total & \\
\hline $\begin{array}{l}\text { Unilateral } \\
\text { tubal block }\end{array}$ & 5.76 & 03 & 7.14 & 02 & 6.25 & 05 \\
\hline $\begin{array}{l}\text { Bilateral } \\
\text { tubal block }\end{array}$ & 19.23 & 10 & 21.43 & 06 & 20 & 16 \\
$\begin{array}{l}\text { Both tubes } \\
\text { patent }\end{array}$ & 75.01 & 39 & 71.43 & 20 & 73.75 & 59 \\
\hline
\end{tabular}

On chromopertubation (Table 7), Ten (19.23\%) of primary and six $(21.43 \%)$ of secondary infertility group had bilateral tubal block and three $(5.76 \%)$ of primary and two $(7.14 \%)$ of secondary infertility cases had unilateral tubal block.

\section{DISCUSSION}

The incidence of primary infertility was $65 \%$ and secondary infertility was $35 \%$ in the present study as found in the study of Sharma et al $(67.2 \%$ and $32.8 \%)$ and Nakade KD et al (69.4\% and $30.6 \%)$. $^{4,5}$

$61.54 \%(\mathrm{n}=32)$ of cases of primary infertility and $57.14 \%(n=16)$ of cases of secondary infertility were in age group 25-34 yrs. This was similar to the study by Mehta AV et al who reported mean age of 31.1 14.5 years. for secondary and $28.8 \pm 3.7$ years for primary infertility. ${ }^{6}$

Hysteroscopy revealed intrauterine septum and endometrial polyp in $12.5 \%$ of 80 cases. Nayak et al had similar findings in their retrospective study of 300 patients of role of diagnostic hysterolaparoscopy in the evaluation of infertility. ${ }^{7}$ Septate uterus is the commonest 
mullerian abnormality. The prevalence of septate uterus in women with recurrent pregnancy loss is approximately $3.5 \%$ as against $1 \%$ in general. ${ }^{8}$ The recent consensus is to treat the septum prophylactically as the septum is the cause for recurrent pregnancy loss with abortion rate ranging from $26 \%$ to $94 \% .^{9}$ An HSG cannot differentiate between a septate uterus and bicornuate uterus. Hence all such cases should be subjected to hysteroscopic examination. Shokier et al in their study of combined DHL in 612 infertile patients found that the rate of diagnosis of significant lesions by laparoscopy rose from $64.3 \%$ to $76.6 \%$ when the hysteroscopic findings were included. ${ }^{10}$ Cumming DC also found a similar increase from $49.4 \%$ to $66 \% .{ }^{11}$ Shokeir et al in another study found 36 cases of endometrial polyp out of 224 cases of hysteroscopy. ${ }^{12}$ As in this study, most of the polyps were located in utero-tubal junction. They achieved pregnancy rate of $50 \%$ after polypectomy. Present study had the hysteroscopic findings of 3 cases of septate uterus, all in primary infertility group and two cases of subseptate uterus in secondary infertility group that were simultaneously resected. Monica RL et al found an incidence of uterine septum to be $33 \%$ in their study of 343 patients and their association with endometriosis. ${ }^{13}$ Vaid et al had compared HSG with Hysteroscopy and found that HSG could not detect uterine pathology in $32.1 \%$ of cases with a sensitivity of $21.3 \%$. $39.89 \%$ of their cases benefitted by one step procedure of hysterolaparoscopic intervention and further treatment. ${ }^{14}$

The laparoscopic finding in the present study showed $23.75 \%$ (19 cases)with various degree of pelvic adhesions. $13.75 \%$ (11 cases) had mild to severe form of pelvic endometriosis and 1 case with endometrioma .Similar to our study, Zhang et al in their study of 132 patients detected endometriosis $(29.55 \%)$ and pelvic inflammatory disease $(59.09 \%)$ as the most common laparoscopic abnormality and uterine polyp as the most common intrauterine pathology $(39.39 \%) .{ }^{15}$ Corson et al in their study revealed endometriosis and peritubal adhesions as the commonest unsuspected pathology at laparoscopy (21-68\%) with normal HSG, the reason being altered tubo-ovarian relationship or release of cytokines that may explain the unexplained infertility. ${ }^{16}$ In the present study, 11 cases underwent laparoscopic adhesiolysis and 10 cases underwent fulguration and ablative therapy of endometriotic areas. Tulandi et al did a single nonrandomized study comparing adhesiolysis for periadnexial adhesions versus no treatment. ${ }^{17}$ Their study showed significant increase in cumulative pregnancy rates (32\% versus $1 \%$ ) at twelve months follow up.

Tubal factors account for $25-35 \%$ of female infertility. $10-25 \%$ of them are due to proximal tubal occlusion. A block in cornul and isthmic region can be detected by hysterosalpingography. But a fimbrial block or tubal block due to peritubal adhesions can be observed at laparoscopy. According to Fortier and Haney, the most frequent lesion is obstructive fibrosis in $38.1 \%$ followed by salpingitis isthmica nodosa in $23.8 \% .^{18}$ In the present case, hysteroscopic examination revealed 3 cases $(10.71 \%)$ out of four in secondary infertility group with tubal ostia fibrosis suggestive of tubal block. The incidence of tubal pathology was found to be $18.75 \%$ cases (9 of primary infertility and 6 of secondary infertility cases). Arpitha et al in their study reported $60 \%$ patients having features of genital T.B with various tubal conditions like hydrosalpinx $(15.9 \%)$, short and rigid tubes $(4.3 \%)$, fimbrial phimosis $(8.7 \%)$, tubal sacculation $(20.2 \%)$, cornual block $(21.7 \%)$ and endometriosis (13.1\%) on laparoscopic visual examination. ${ }^{19}$ All the 15 cases in the present study with similar tubal pathology were tested for GTB. Out of them 7 cases later reported positive for T.B and were promptly started on AKT regimen.

The chromopertubation test revealed higher incidence of bilateral tubal block in cases of secondary infertility group similar to the study of Nayak et al. ${ }^{7}$ The 16 cases of bilateral tubal block were advised to go to ART centres. Cervical lesions in the present study was $3.75 \%$ Jain $\mathrm{N}$ et al had similar observation $(5.3 \%)$ in their study. ${ }^{20}$ In a study of 520 unexplained infertile patients with normal HSG by Tsuji I et al, the cumulative pregnancy rates following laparoscopic surgery after 6, 12 and 18 months were $44.8 \%, 72.4 \%$ and $79.3 \%$ respectively. ${ }^{21}$ In the present study, 36 of total 80 cases $(52 \%$ of primary and $32.14 \%$ of secondary infertility) had no significant findings on DHL. They are grouped here as unexplained infertility.

Fertility may be adversely affected by a variety of occupational chemical exposures. These agents can inflict damage on the genetic material of the cells or can have adverse effects on their sexual functions and fertility. Volatile organic solvents, chemical dusts, pesticides are reproductive toxins that may cause defects in ovulatory functions, tubal factors infertility like fibrosis, adhesions and endometriosis. ${ }^{22}$ Present study has shown high incidence of pelvic adhesions, endometriosis and tubal factors like ostial fibrosis among all causative factors of infertility. As this study is conducted among a small section of women from industrial area, it is inconclusive and a more detailed prospective study in a larger group of industrial population is recommended to prove whether industrial toxin exposure is the reason for a relatively higher incidence of tuboperitoneal factors causing infertility among these women.

\section{CONCLUSION}

In conclusion, DHL procedure though invasive, remains the gold standard diagnostic modality, as it explains 30$70 \%$ of pathology that goes undetected and unexplained during the routine investigative workup of female infertility. This diagnostic procedure also gives an opportunity to do simultaneous therapeutic interventions whenever required under the same sitting and anaesthesia, thereby reducing the hospital stay and cost, effectively. 


\section{ACKNOWLEDGMENTS}

Authors thank the almighty, the ESIC organization and the entire operation theatre staff including the anesthesiologists to give the authors the opportunity and resources for the research and for uneventful conducting of the surgical procedures.

Funding: No funding sources

Conflict of interest: None declared

Ethical approval: Not required

\section{REFERENCES}

1. Practice committee of American society of Reproductive Medicine. Definition of infertility and Recurrent pregnancy loss: a committee opinion. Fertil Steril. 2013;99:63.

2. Cramer DW, Walker A, Schiff I. Statistical method in evaluating the outcome of infertility therapy. Fertil Steril. 1979;32:80-6.

3. Dunson DB, Baird DD, Colombo B. Increased infertility with age in men and women. Obstet Gynecol. 2004;103:51-6.

4. Sharma R, Taby A, Guleri AS. Laparoscopic evaluation of cases of primary and secondary infertility. J Obs Gyn India. 1997;47:366-71.

5. Nakade KD, Deokar SS. Comparative evaluation of laparoscopy and hysterosalpingography in infertility. J Obs Gyn India.1993;43:784-7.

6. Mehta AV, Modi AP, Raval BM, Munshi SP, Patel SB, Dedharotiya SM. Role of diagnostic hysterolaparoscopy in the evaluation of infertility. Int J Reprod Contracept Obstet Gynecol. 2016;5:437-40.

7. Nayak PK, Mahapatra PC, Mallik JJ, Swain S, Subarna M, Jayaprakash S. Role of diagnostic hysterolaparoscopy in the evaluation of infertility: a retrospective study of 300 patients. J Hum Reprod Sci. 2013;6(1):32-4.

8. Homer HA, Li TC, Cooke ID. The septate uterus: a review of management and reproductive outcome. Fertil Steril. 2000;73:1-14.

9. Bakas P, Gregoriou O, Hassiakos D, Liapis A, Creatsas M, Konidaris S. Hysteroscopic resection of uterine septum and reproductive outcome in women with unexplained infertility. Gynecol Obstet Invest. 2012;73(4):321-5.

10. Shokeir TA, Shalan HM, ElShafei MM. Combined diagnostic approach of laparoscopy and hysteroscopy in the evaluation of female infertility: results of 612 patients. J Obstet Gynaecol Res. 2004;30(1):9-14.

11. David C, Taylor PJ. Combined laparoscopy and hysteroscopy in the investigation of the ovulatory infertile female. Fertil Steril. 1980;33(5):475-8.
12. Shokeir TA, Shalan HM, El-Shafei MM. Significance of endometrial polyps detected hysteroscopically in eumenorrhoeic infertile women. J Obstet Gynaecol Res. 2004;30:84-9.

13. Monica RL, Pinto J, Luciano D, Lyapis A, Luciano A. Incidence of sepate uterus in reproductive-aged women with and without endometriosis. J Min Inv Gynecol. 2016;23(4):610-3.

14. Vaid K, Mehra S. Pan endoscopic approach Hysterolaparoscopy as an initial procedure in selected infertile women. J Clin Diagn Res. 2014;8(2):95-8.

15. Erhong Z, Yanan Z, Fang L, Gu J. Combined Hysterolaparoscopy for the diagnosis of female infertility: a retrospective study of 132 patients in China. Mater Socio Med. 2014;26(3):156-7.

16. Corson SL, Cheng A, Gutmann JN et al. Laparoscopy in the 'normal' infertile patient: a question revisited. J Am Assoc Gynecol Laparosc. 2000;7:317-24.

17. Tulandi T, Collins JA, Burrows E. Treatment dependent and treatment independent pregnancy among women with periadnexial adhesions. Am J Obstet Gynaecol. 1990;162:354-7.

18. Fortier KJ, Haney AF. The pathologic spectrum of uterotubal junction obstruction. Obstet Gynaecol. 1985;65(1):93-8.

19. Arpitha VJ, Channaveeregowda S, Nagarathnamma R. Diagnosis of genital tuberculosis: correlation between polymerase chain reaction positivity and laparoscopic findings. Int $\mathrm{J}$ Reprod Contracept Obstet Gynaecol. 2016;5(10):3425-32.

20. Jain N. Role of hysteroscopy in evaluation of infertility: a retrospective study of 100 cases. J Gynecol. 2016;1(3):000117.

21. Tsuji I, Ami K, Miyazaki A, Hujinami N, Hoshiai H. Benefit of diagnostic lparoscopy for patients with unexplained infertility and normal hysterosalpingography findings. Tohoku J Exp Med. 2009;219:39-42.

22. Smith EM, Hammonds-Ehlers M, Clark MK, Kirchner HL, Fuortes L. Occupational exposures and risk of female infertility. J Occup Environ Med. 1997;39(2):138-4.

Cite this article as: Kanungo L, Haritha M, Chaitanya N, Sangeetha K. Evaluation of infertility in women from an industrial area in Telangana, India by diagnostic hysterolaparoscopy: can it explain the unexplained?. Int J Reprod Contracept Obstet Gynecol 2018;7:2164-9. 